Penelitian

\title{
Prevalensi dan Faktor Risiko Infeksi Cacing Saluran Pencernaan pada Kuda Delman di Kota Bogor
}

\author{
Prevalence and Risk Factor of Gastrointestinal Helminth Infections \\ in Delman Horses in City of Bogor
}

\author{
Hadzash Peppyrhanggasidhi Shatyaayyupranathasari', Etih Sudarnika², Yusuf Ridwan ${ }^{3^{*}}$
}

\author{
1Program Sarjana Kedokteran Hewan, Fakultas Kedokteran Hewan, \\ Institut Pertanian Bogor, Indonesia \\ 2Divisi Kesehatan Masyarakat Veteriner dan Epidemiologi, Departeman Ilmu Penyakit Hewan dan Kesehatan Masyarakat \\ Veteriner, Fakultas Kedokteran Hewan, Institut Pertanian Bogor, Indonesia \\ ${ }^{3}$ Divisi Parasitologi dan Entomologi Kesehatan, Departeman Ilmu Penyakit Hewan dan Kesehatan Masyarakat Veteriner, \\ Fakultas Kedokteran Hewan, Institut Pertanian Bogor, Indonesia \\ *Penulis untuk korespondensi yusufridwan67@yahoo.com \\ Diterima 6 Februari 2021, Disetujui 25 Juni 2021
}

\begin{abstract}
ABSTRAK
Kecacingan pada kuda merupakan penyakit yang dapat mempengaruhi kesehatan dan performa kuda termasuk pada kuda delman. Penelitian ini bertujuan menduga prevalensi dan mengidentifikasi faktor-faktor risiko kejadian infeksi cacing saluran pencernaan pada kuda delman di Kota Bogor. Metode penelitian ini yaitu studi cross-sectional, menggunakan dua jenis data berupa hasil pemeriksaan laboratorium sampel feses dan hasil wawancara terhadap kusir delman menggunakan kuesioner terstruktur. Data dianalisis untuk menentukan rataan derajat infeksi cacing dan proporsi kuda yang terinfeksi serta pendugaan nilai risiko relatif (RR). Hasil penelitian 20 sampel feses menunjukkan prevalensi Strongyle sebesar 60\%. Berdasarkan hasil identifikasi larva, jenis Strongyle terdiri atas Cyathostominae $73 \%$ (Cyathostominae tipe A $61 \%$, tipe G $6 \%$, tipe C $4 \%$, tipe F $1 \%$, dan tipe $\mathrm{H} 1 \%$ ), Strongylus vulgaris $22 \%$, S. equinus $3 \%$, serta $S$. edentatus 2\%. Derajat infeksi Strongyle termasuk kategori infeksi ringan dengan jumlah 282.5 telur tiap gram tinja (TTGT). Faktor risiko yang mempunyai hubungan terhadap kejadian infeksi Strongyle yaitu umur kuda, kepadatan populasi, jenis kandang dan pakan kuda, lokasi dan cara pemotongan rumput, higiene kuda, serta sanitasi. Perbaikan manajemen pemeliharaan kuda perlu dilakukan oleh para pemilik kuda untuk menurunkan kejadian infeksi cacing saluran pencernaan.
\end{abstract}

Kata kunci: Cyathostominae, faktor, kuda, prevalensi, Strongyle

\begin{abstract}
Helminth infection is a diseases that influence health and performance of horse. This study aimed to estimate prevalence and identify risk factors related to gastrointestinal helminth infections in delman horse in Bogor. This research method was a cross-sectional study, using two types of data, namely laboratory examination result of fecal sample and structured questionnaire data from delman coachman. Those data were analyzed to determine helminth infection degree's and infected horse proportion and relative risk (RR) values. The results of 20 fecal samples examination showed $12(60 \%)$ horses were infected with the Strongyle. Based on larval identification results, Strongyle types consisted of Cyathostominae $73 \%$ (Cyathostominae type A $61 \%$, type $G 6 \%$, type C $4 \%$, type $\mathrm{F} 1 \%$, and type $\mathrm{H} 1 \%$ ), Strongylus vulgaris $22 \%$, S. equinus $3 \%$, and S. edentatus $2 \%$. The degree of Strongyle infection was in the mild infection category with the number of eggs per gram (EPG) of feces was 282.5. Risk factors related to the Strongyle infection were the age of a horse, population density, type of horse feed and shed, location and way cutting the grass, horse's hygiene, and sanitation. Improved management of rearing horses are needed by the horse owner to control gastrointestinal helminth infections.
\end{abstract}

Keywords: Cyathostominae, factor, horse, prevalence, Strongyle 


\section{PENDAHULUAN}

Kuda merupakan hewan yang sering digunakan sebagai alat angkut atau transportasi dalam bentuk kuda tarik atau delman di berbagai negara, termasuk Indonesia. Kuda memiliki kekuatan yang besar, mempunyai daya jelajah yang luas, serta dapat digunakan dalam berbagai medan sekaligus, sehingga tidak salah jika kuda menjadi transportasi tradisional yang sangat digemari pada masanya (ANRI, 2017). Seiring perkembangan zaman, peran kuda sebagai alat transportasi tradisional mulai menurun bahkan beralih fungsi. Meskipun fungsinya telah beralih, data terbaru pertumbuhan populasi kuda di Indonesia menunjukkan peningkatan di tahun 2019 sebesar $4.11 \%$ dengan Bogor menyumbangkan sekitar $0.2 \%$ populasi kuda di Indonesia (Ditjen PKH, 2019). Peran kuda saat ini lebih banyak dikembangkan untuk kuda pacu, tunggang, pasukan kepolisian, kavaleri, maupun equestrian atau atlet, meskipun di beberapa daerah kuda masih digunakan sebagai kendaraan wisata, salah satunya di Kota Bogor.

Faktor keberhasilan pengembangan ternak kuda sangat ditentukan oleh manajemen kesehatannya, selain manajemen feeding dan breeding. Manajemen pemeliharaan yang buruk dapat membuat kuda mudah terserang penyakit (Fathmanto, 2008). Penelitian Wenda et al. (2020) di Minahasa menunjukkan bahwa infeksi cacing parasit merupakan kasus penyakit yang paling banyak menyerang ternak kuda. Infeksi parasit dapat menimbulkan gangguan kesehatan dan kebugaran pada inang (Soares et al., 2014), bahkan menyebabkan kematian ketika infeksi cacing bersifat parah (Fowler \& Mikota, 2006). Kuda dapat terinfeksi cacing parasit karena memakan pakan hijauan yang tercemar telur atau larva infektif (Widnyana, 2013). Beberapa cacing seperti Strongyle besar (Strongylus spp.) dan kecil (Cyasthostomes), Ascarid, Oxyuris equi (cacing keremi), Gastrophilus spp., Metastrongylus spp. (cacing pada paru-paru), Gastrodiscus sp. dan Pseudodiscus sp. (cacing daun), serta Anoplocephala spp. dan Paranoplocephala sp. (cacing pita) merupakan spesies cacing yang dapat menginfeksi kuda. Umumnya, infeksi campuran dari beberapa spesies cacing paling banyak ditemukan menginfeksi kuda. Lem et al. (2012) melaporkan infeksi oleh beberapa jenis parasit (92.28\%) pada kuda lebih umum dibandingkan infeksi oleh satu jenis parasit (7.72\%). Penelitian mengenai cacing parasit pada kuda delman di Kota Bogor perlu dilakukan untuk menyediakan pembaruan informasi berkaitan dengan jenis cacing parasit dan faktor-faktor yang mempengaruhi kejadian kecacingan.

\section{BAHAN DAN METODE}

\section{Rancangan Penelitian}

Penelitian ini dilakukan di Kota Bogor dengan mengambil sampel kuda delman yang digunakan sebagai alat transportasi untuk wisatawan keliling Kebun Raya Bogor. Penelitian ini merupakan kajian observasional cross-sectional yang menggunakan dua jenis data, yaitu data hasil pemeriksaan sampel feses di laboratorium dan data hasil wawancara terhadap kusir delman. Feses kuda diambil sebanyak 20 sampel pada seluruh kuda delman yang beroperasi di Kota Bogor selama kurun waktu penelitian. Lokasi operasional delman yaitu di depan Istana Bogor dan Taman Yasmin. Pengambilan sampel feses dilakukan setiap minggu pada kuda delman yang berbeda. Sampel yang diambil selanjutnya dibawa ke laboratorium untuk dilakukan pemeriksaan. Pemeriksaan sampel feses dilakukan untuk mengetahui adanya telur cacing dengan menggunakan metode pengapungan sederhana (uji kualitatif), McMaster (uji kuantitatif), dan filtrasi bertingkat (deteksi telur cacing Trematoda). Telur yang ditemukan diidentifikasi berdasarkan bentuk dan ukuran telur. Sebagai pemeriksaan lanjutan, pemupukan feses dilakukan untuk mengetahui jenis Strongyle melalui idenfikasi larva infektif (L3). Wawancara dilakukan secara langsung dengan menggunakan kuisioner terstruktur dan responden yang diwawancarai adalah seluruh kusir delman yang menarik kuda saat jam operasional pada kurun waktu penelitian. Data yang diperoleh dianalisis untuk mengetahui derajat infeksi, prevalensi dan faktor risiko infeksi cacing parasit.

\section{Prosedur Penelitian}

\section{Pengambilan Sampel Feses}

Sampel diambil dari tempat penampungan feses kuda saat jam operasional delman, sekitar pukul 08.00-13.30 WIB. Sampel selanjutnya dimasukkan ke dalam plastik klip. Sampel feses tersebut diberi label yang berisi informasi nama, umur, dan jenis kelamin kuda. Sampel feses dimasukkan ke dalam cool box selama perjalanan dan sesampainya di laboratorium disimpan di dalam refrigerator pada suhu 4 sampai $6{ }^{\circ} \mathrm{C}$ hingga feses tersebut dilakukan pemeriksaan. 
Metode Pengapungan Sederhana.

Timbangan digital dikalibrasi terlebih dahulu, kemudian sampel feses ditimbang sebanyak 4 gram dalam gelas sampel. Sebanyak $56 \mathrm{ml}$ larutan gula jenuh ditambahkan ke dalam gelas sampel dan diaduk hingga homogen. Setelah itu, larutan sampel disaring dengan saringan teh sebanyak 4-5 kali dan dituangkan ke dalam tabung reaksi hingga permukaannya membentuk meniskus cembung. Mulut tabung ditutup dengan cover glass dan didiamkan selama 5 menit. Cover glass diangkat kemudian diletakkan di atas object glass. Pengamatan dilakukan menggunakan mikroskop dengan perbesaran 10x lensa objekif.

\section{Metode McMaster}

Suspensi feses dan larutan yang digunakan dalam pemeriksaan teknik pengapungan dimasukkan ke dalam dua kamar hitung McMaster dengan menggunakan pipet Pasteur. Kamar hitung tersebut diperiksa menggunakan mikroskop dengan perbesaran $10 x$ lensa objektif. Jumlah telur tiap gram tinja (TTGT) diperoleh dengan menjumlahkan telur yang ditemukan pada kedua kamar hitung McMaster dan hasil kemudian dikalikan denagn 50 (Zajac \& Conboy, 2012).

\section{Filtrasi Bertingkat}

Metode filtrasi bertingkat dilakukan untuk mendeteksi adanya telur cacing Trematoda dalam sampel feses. Sampel feses ditimbang sebanyak 4 gram dan ditambahkan $56 \mathrm{ml}$ akuades, lalu diaduk hingga homogen. Setelah itu, larutan sampel disaring menggunakan saringan teh 4-5 kali. Larutan sampel hasil saringan difiltrasi dengan saringan bertingkat, berturut-turut dengan saringan $400 \mu \mathrm{m}, 100 \mu \mathrm{m}$, dan $45 \mu \mathrm{m}$. Filtrat yang terperangkap pada saringan $45 \mu \mathrm{m}$ ditampung dalam cawan petri. Partikel filtrat yang masih tersangkut dapat dibantu dengan menyemprotkan akuades dengan menggunakan botol semprot. Selanjutnya, sampel hasil filtrasi diambil menggunakan pipet Pasteur dan diteteskan ke object glass yang telah dimodifikasi untuk diperiksa menggunakan mikroskop (Willingham et al., 1998).

\section{Identifikasi Larva Infektif (L3) Strongyle}

Identifikasi larva infektif (L3) Strongyle merupakan pemeriksaan untuk mengetahui cacing Strongyle sampai tingkat genus atau spesies. Feses yang mengandung telur tipe Strongyle dipupuk untuk menghasilkan L3. Feses yang akan dibuat pupuk ditempatkan pada cawan petri kemudian ditambahkan vermiculate dengan perbandingan volume feses 1:3 dan diaduk hingga merata. Pupukan ditambah sedikit air untuk menjaga kelembaban dan ditutup dengan tutup cawan petri kemudian dicantumkan label. Pupukan larva disimpan pada suhu kamar selama 7 hari.

Saat pemanenan, pupukan larva dibungkus menggunakan kain tile berukuran $\pm 15 \times 15 \mathrm{~cm}^{2}$ kemudian dimasukkan pada gelas Baermann yang berisi akuades dengan posisi menggantung dan terendam. Larva akan terkumpul di bagian dasar gelas setelah beberapa jam. Larva diambil menggunakan pipet kemudian dimasukkan dalam tabung koleksi dan disimpan di dalam refrigerator. Pengamatan L3 Strongyle dilakukan dengan cara meneteskan suspensi L3 dari tabung koleksi di atas object glass kemudian ditambahkan larutan lugol dan ditutup dengan cover glass. Pengamatan dilakukan menggunakan mikroskop dengan perbesaran 40x lensa objektif untuk mengidentifikasi larva infektif (L3). Pengamatan dilakukan terhadap morfologi L3 yang meliputi bentuk esofagus, bentuk anterior, panjang selubung larva di bagian ekor, serta jumlah dan pola susunan sel usus. Identifikasi dilakukan berdasarkan kunci identifikasi larva infektif pada kuda menurut Bevilaqua et al. (1993) dan Santos et al. (2018).

\section{Analisis Data}

Hasil pemeriksaan jenis telur cacing dianalisis dengan menduga rataan derajat infeksi cacing dan proporsi kuda yang terinfeksi pada selang kepercayaan $95 \%$. Pendugaan nilai risiko relatif (RR) dengan selang kepercayaan $95 \%$ dilakukan untuk menganalisis hubungan antara faktor risiko dengan kejadian infeksi cacing saluran pencernaan pada kuda. Data dianalisis dengan menggunakan software Microsoft Excel $^{\circledast} \quad 2016$ dan Epitools (https://epitools.ausvet.com.au/).

\section{HASIL}

\section{Jenis Cacing Saluran Pencernaan pada Kuda}

Hasil pemeriksaan 20 sampel feses kuda delman di Kota Bogor menunjukkan bahwa 12 (60\%) sampel positif terinfeksi hanya oleh Nematoda Strongyle. Penelitian ini tidak menemukan baik cacing dari kelas Trematoda maupun Cestoda. Nematoda Strongyle 
memiliki telur dengan tipe Strongylid (Gambar 1). Tipe telur Strongylid berbentuk lonjong dengan ukuran panjang sekitar 80-100 $\mu \mathrm{m}$ (ESCCAP, 2019) dan lebar yang bervariasi. Umumnya, telur ini berdinding tipis dan mengandung blastomer dengan jumlah yang berbeda-beda. Telur Strongyle yang ditemukan pada sampel feses kuda delman di Kota Bogor berbentuk lonjong, berdinding tipis, serta mengandung blastomer seperti buah anggur, sesuai dengan yang dideskripsikan Andersen et al. (2013).

Hasil identifikasi larva infektif (L3) Strongyle menunjukkan bahwa ada 3 jenis larva dari kelompok Strongyle besar dan 5 jenis larva dari kelompok Strongyle kecil (Cyathostominae) (Tabel 1). Cyathostominae tipe A memiliki persentase sebesar $61 \%$ kemudian diikuti Strongylus vulgaris sebesar $22 \%$. Berdasarkan struktur morfologi L3 (Gambar 2), larva Cyathostominae memiliki tubuh memanjang, bagian anterior meruncing, selubung bergerigi dengan ekor panjang, dan sel-sel usus yang terdefinisi dengan baik. Perbedaan utama L3 S. vulgaris dengan Cyathostominae tipe A yaitu jumlah dan pola susunan sel usus. Pada Strongyle besar, L3 S. equinus dan S. edentatus belum memiliki sel usus yang cukup banyak sehingga kadang-kadang tampak bertumpang-tindih, menyebabkan kesulitan dalam menentukan jumlah sel ususnya (Bevilaqua et al. 1993).

\section{Prevalensi dan Derajat Infeksi Kecacingan}

Hasil pemeriksaan 20 sampel feses kuda delman di Kota Bogor menunjukkan bahwa tingkat kejadian infeksi untuk Strongyle sebesar 60\% (SK 95\%: 38.5-
81.5), sedangkan derajat infeksinya sebesar 282.5 TTGT (SK 95\%: 6.9-558.1). Derajat infeksi dapat dibagi ke dalam beberapa kategori berdasarkan jumlah TTGT, yaitu infeksi ringan jika jumlah telur 1499 butir per gram, infeksi sedang jika jumlah telur 500-5000 butir per gram, dan infeksi berat jika telur yang dihasilkan $>5000$ butir per gram tinja (Thienpont et al., 1995). Hasil penelitian menunjukkan bahwa derajat infeksi Strongyle pada penelitiaan ini termasuk kategori infeksi ringan.

\section{Hubungan Faktor Resiko terhadap Infeksi Cacing Saluran Pencernaan}

Faktor risiko yang diduga memiliki hubungan terhadap infeksi cacing saluran pencernaan pada kuda delman di Kota Bogor dapat dilihat pada Tabel 2. Faktor risiko tersebut dapat berupa faktor intrinsik berupa ras, umur, dan jenis kelamin kuda; serta faktor ekstrinsik berupa manajemen pemeliharaan dan lingkungan. Berdasarkan hasil analisis, variabel intrinsik yang berasosiasi terhadap kejadian kecacingan yaitu umur kuda, sedangkan faktor ekstrinsik yang berasosiasi meliputi kepadatan populasi, jenis kandang kuda, tipe tempat minum, jenis pakan kuda, lokasi dan cara pemotongan rumput, frekuensi kuda dimandikan dan di-grooming, gejala klinis kuda, serta cara membersihkan kandang kuda dan tempat penampungan feses.

Hasil penelitian menunjukkan bahwa kuda yang berumur <4 tahun (1.9; SK 95\% RR: 1.2-3.0), kuda yang berjumlah $>2$ ekor dalam satu lokasi pemeliharaan (2.4; SK 95\% RR: 1.1-5.5), jenis kandang

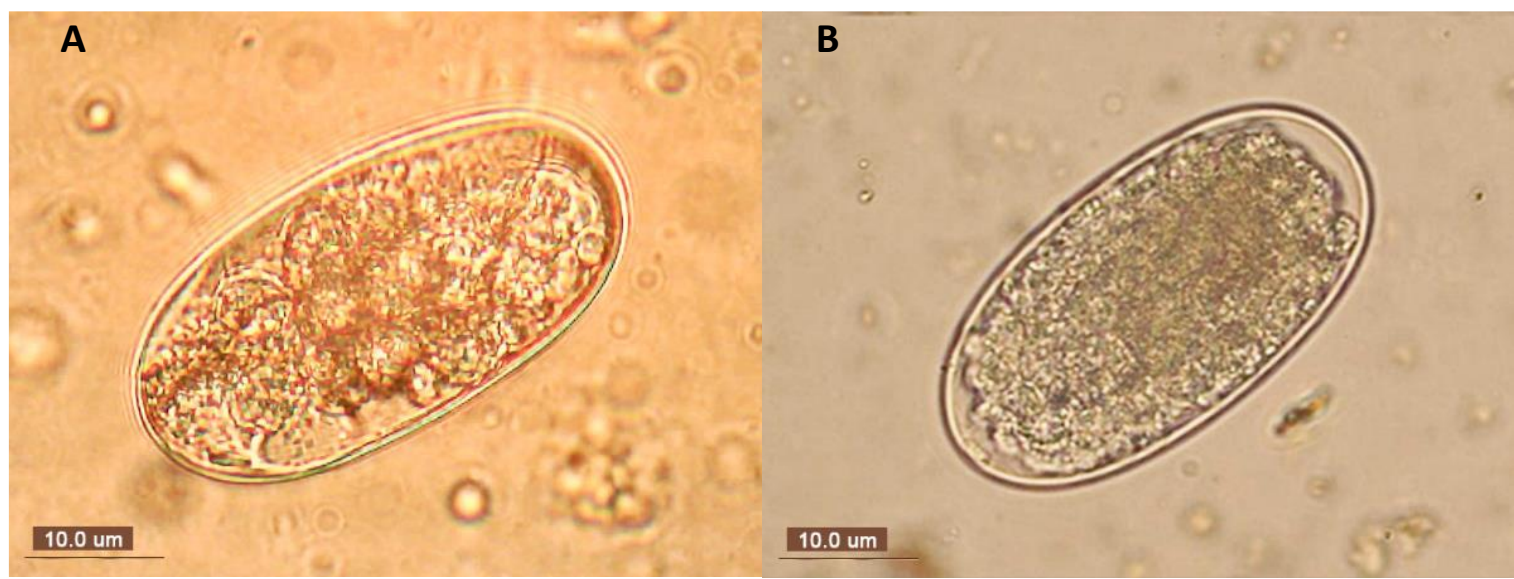

Gambar 1 Morfologi telur Strongyle pada sampel feses (A); morfologi telur Strongyle menurut Andersen et al. (2013) (B) 
Tabel 1 Persentase jenis larva infektif (L3) Strongyle yang menginfeksi kuda delman di Kota Bogor

\begin{tabular}{|c|c|c|c|c|}
\hline \multicolumn{2}{|c|}{ Jenis larva } & 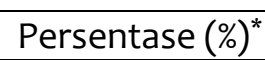 & Jenis larva & Persentase (\%) $^{*}$ \\
\hline \multicolumn{2}{|c|}{ Strongyle kecil } & & Strongyle kecil & \\
\hline \multirow{8}{*}{ Cyathostominae ${ }^{* *}$} & tipe $A$ & 61 & Gyalocephalus capitatus & 0 \\
\hline & tipe $B$ & 0 & Poteriostomum spp. & 0 \\
\hline & tipe C & 4 & & \\
\hline & tipe D & 0 & Strongyle besar & \\
\hline & tipe $\mathrm{E}$ & 0 & Strongylus equinus & 3 \\
\hline & tipe $\mathrm{F}$ & 1 & Strongylus edentatus & 2 \\
\hline & tipe $G$ & 6 & Triodontophorus spp. & 0 \\
\hline & tipe $\mathrm{H}$ & 1 & Strongylus vulgaris & 22 \\
\hline
\end{tabular}

${ }^{*}$ Persentase dari 100 cacing parasit yang ditemukan.

${ }^{* *}$ Cyathostominae, tipe A: Cylicocyclus insigne, Cc. nassatus, Cc radiatus, Cylicostephanus minutus, Cyathostomum catinatum, Cy. pateratum, Petrovinema poculatum; B: Cc. brevicapsulatus, Cc ultrajectinus, Cylicodontophorus bicornatus; C: Cyl. calicatus, Cyl. hybridus.

kuda yang tertutup (2; SK 95\% RR: 1.2-3.2), jenis pakan berupa ampas tempe atau tahu (3; SK 95\% RR: 1.1-7.9), lokasi pemotongan rumput selain di sekitar pematang sawah (2.1; SK 95\% RR: 1.3-3.7), cara pemotongan rumput dengan meninggalkan bagian $<10 \mathrm{~cm}$ dari permukaan tanah (2; SK 95\% RR: 1.2-3.3), kuda yang tidak dimandikan setiap hari (2; SK 95\% RR: 1.1-3.7), serta tipe tempat minum kuda yang berbahan dasar semen (1.8; SK 95\% RR: 1.2-2.7) memiliki risiko terinfeksi cacing saluran pencernaan berupa Strongyle lebih besar dibandingkan beberapa variabel tertentu, seperti yang ditunjukkan pada Tabel 2.

\section{PEMBAHASAN}

Hasil penelitian ini menunjukkan bahwa kuda delman di kota Bogor hanya terinfeksi oleh nematoda kelompok Strongyle, yaitu Strongyle besar dan Strongyle kecil (Cyathostominae). Beberapa penelitian menunjukkan bahwa 5-15 spesies Cyathostominae memang umum ditemukan pada kuda (Kooyman et al., 2016; Kuzmina et al., 2016). Strongyle besar yang merupakan genus Strongylus memiliki empat spesies yang patogen, yaitu S. asini, S. edentatus, S. equinus, dan S. vulgaris. Spesiesspesis tersebut dapat menyebabkan kolik dan bahkan kematian pada kuda (Lyons \& Tolliver, 2015). Strongylus vulgaris merupakan spesies parasit paling berbahaya pada kuda. Migrasi L4 cacing ini dapat menyebabkan arteritis, trombosis, dan emboli $a$. cranial mesenterica cranial (Urquhart et al., 1996). Adanya trombi dan emboli pada pembuluh darah dapat menghalangi laju aliran darah sehingga mengakibatkan kolik dan kemungkinan kematian pada kuda karena kurangnya suplai darah ke usus (Lyons \& Tolliver, 2015). Patogenitas Strongyle kecil (Cyathostominae) lebih rendah jika dibandingkan dengan Strongylus spp., karena larva Cyathostominae tidak bermigrasi di luar usus, hanya melakukan penetrasi ke dalam kolon (Lyons \& Tolliver, 2015).

Penelitian ini juga menunjukkan tingkat kejadian dan derajat infeksi Strongyle pada kuda delman di Kota Bogor termasuk kategori infeksi ringan. Meskipun tingkat infeksi cacing termasuk kategori infeksi ringan, adanya infeksi dapat membuat gangguan pada saluran pencernaan tanpa harus menunjukkan tanda-tanda klinis yang pasti, seperti berkurangnya penyerapan nutrisi, gangguan keseimbangan microflora pada ususdan menurunkan imunitas untuk melawan patogen usus lain (Succeed, 2015). Kuda dengan tingkat infeksi cacing yang ringan dapat dilakukan pengobatan dengan pemberian antelmintik untuk mengurangi transmisi dan risiko kejadian infeksi cacing.

Faktor yang mempengaruhi prevalensi infeksi cacing parasit yang ditunjukkan pada penelitian ini diantarnya adalah faktor intrinsik yaitu umur hewan. Hasil penelitian menunjukkan bahwa kuda yang berumur <4 tahun memiliki risiko terinfeksi cacing saluran pencernaan Strongyle 1.9 lebih besar (SK 95\% RR: 1.2-3.0) dibandingkan kuda yang berumur $\geq 4$ tahun. Hasil penelitian ini sejalan dengan penelitian yang dilakukan oleh Mangassa et al. (2016) dan Ashenafi et al. (2015), yang melaporkan infeksi Strongyle lebih tinggi pada hewan muda dibandinkan dengan 


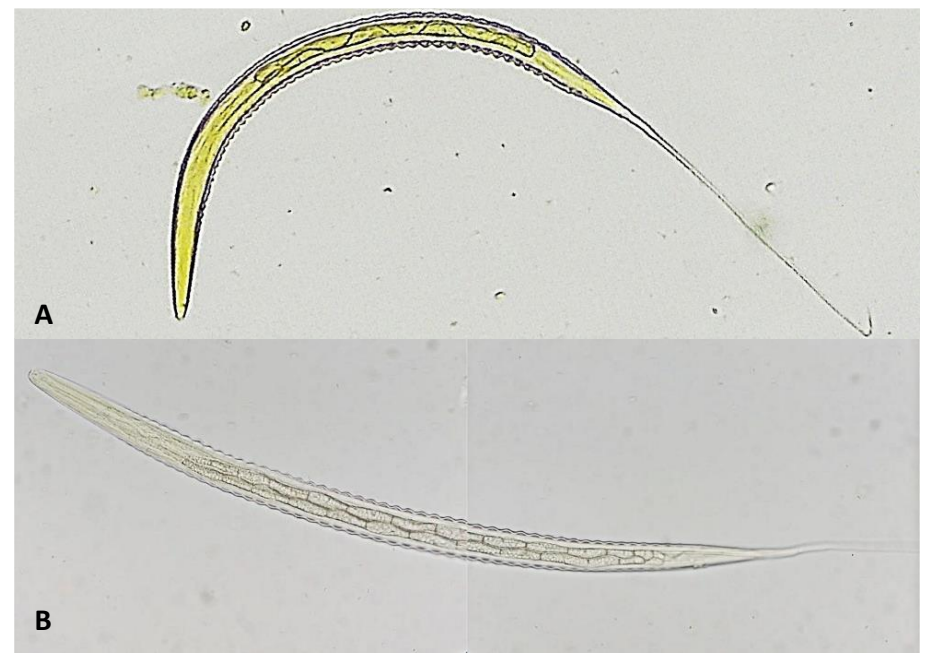

Gambar 2 Struktur morfologi L3 Cyathostominae tipe A (A) dan S. vulgaris (B)

kuda yang lebih tua. Hasil penelitian yang berbeda dilaporkan oleh Sultan et al. (2013) yang menunjukkan bahwa kejadian infeksi $25.7 \%$, 61\% dan $13.2 \%$ pada masing-masing pada hewan muda, dewasa dan tua. Secara umum, infeksi parasit lebih sering terjadi pada anak kuda dan kuda muda karena berkaitan dengan kekebalan kuda (Fritzen et al., 2010; Kornaś et al., 2010; Relf et al., 2013).

Faktor ektrinsik yang mempengaruhi prevalensi infeksi cacing parasit dapat berupa manajemen pemeliharaan dan lingkungan seperti suhu, kelembapan, dan iklim. Berdasarkan analisis faktor berupa kepadatan populasi yang termasuk ke dalam manajemen pemeliharaan, kuda yang berjumlah $>2$ ekor dalam satu lokasi pemeliharaan mempunyai hubungan terhadap kejadian helminthiasis. Kategori variabel ini memiliki risiko terinfeksi Strongyle 2.4 kali lebih besar (SK 95\% RR: 1.1-5.5) dibandingkan kuda yang berjumlah $\leq 2$ ekor dalam satu lokasi pemeliharaan. Kuda yang berjumlah $>2$ ekor diduga dapat menyebabkan tingkat kontaminasi telur atau larva infektif di lingkungan dalam satu lokasi pemeliharaan lebih tinggi jika dibandingkan dengan kuda yang berjumlah $\leq 2$ ekor. Peluang penularan diduga lebih tinggi terdapat pada lokasi pemeliharaan dengan jumlah kuda lebih dari dua ekor. Hal ini dapat menyebabkan peningkatan kejadian reinfeksi. Menurut Harvey et al. (2019), ada perbedaan yang signifikan antara populasi satu dengan populasi lain, yang dikelompokkan berdasarkan lokasi, kepadatan, dan tipe habitat. Setiap individu kuda yang terinfeksi memiliki tingkat infeksi dan kontaminasi lingkungan yang berbeda.
Seringkali, beberapa kuda memiliki tingkat infeksi yang tinggi dan dapat mengekskresikan telur dalam jumlah sedang hingga tinggi ke lingkungan (Matthews \& Burden, 2013).

Jenis kandang kuda yang digunakan juga dapat mempengaruhi tingkat kejadian infeksi Strongyle pada kuda. Berdasarkan hasil penelitian, jenis kandang tertutup memiliki risiko terinfeksi Strongyle 2 kali lebih besar (SK 95\% RR: 1.2-3.2) dibandingkan kandang terbuka. Kandang tertutup diduga memiliki temperatur yang rendah namun kadar kelembaban yang tinggi jika dibandingkan dengan kandang terbuka. Hal ini disebabkan kurangnya paparan sinar matahari di kandang tertutup. Kelembaban yang tinggi dapat memberikan kondisi yang ideal bagi perkembangan cacing. Penetasan telur dan perkembangan L1 ke L3 membutuhkan tingkat kelembaban tanah lebih tinggi dari 15-20\% (Mfitilodze \& Hutchinson, 1987). Telur akan berkembang menjadi L3 dalam 2-3 minggu pada suhu $10-25{ }^{\circ} \mathrm{C}$ dan L3 dapat bertahan selama beberapa minggu bahkan beberapa bulan (Nielsen et al. 2007). Temperatur tinggi serta paparan sinar matahari langsung. di kandang terbuka dapat mengurangi jumlah $\mathrm{L} 3$ yang mengkontaminasi kandang. Menurut Nielsen et al. (2007), L3 akan segera mati jika terpapar kondisi lingkungan yang merugikan, seperti sinar matahari langsung dan perubahan temperatur.

Hasil penelitian menunjukkan bahwa jenis pakan juga dapat mempengaruhi tingkat kejadian infeksi Strongyle pada kuda. Kuda yang diberikan pakan berupa ampas tempe atau tahu memiliki risiko 
Tabel 2 Hubungan faktor risiko terhadap infeksi cacing saluran pencernaan

\begin{tabular}{|c|c|c|c|c|}
\hline \multirow{2}{*}{ Variabel yang diamati } & \multirow{2}{*}{ Jumlah } & \multicolumn{2}{|c|}{ Helminthiasis } & \multirow{2}{*}{$\begin{array}{c}\text { RR } \\
\text { (SK 95\%) }\end{array}$} \\
\hline & & Positif & Negatif & \\
\hline \multicolumn{5}{|l|}{ Umur kuda } \\
\hline$<4$ tahun & 3 & $3(100 \%)$ & $0(0 \%)$ & $1.9(1.2-3.0)^{*}$ \\
\hline$\geq 4$ tahun & 17 & $9(52.9 \%)$ & $8(47.1 \%)$ & Referensi \\
\hline \multicolumn{5}{|l|}{ Jumlah kuda dalam satu lokasi pemeliharaan } \\
\hline$\leq 2$ ekor & 11 & $4(36.4 \%)$ & $7(63.6 \%)$ & Referensi \\
\hline$>2$ ekor & 9 & $8(88.9 \%)$ & $1(11.1 \%)$ & $2.4(1.1-5.5)^{*}$ \\
\hline \multicolumn{5}{|l|}{ Jenis kandang kuda } \\
\hline Kandang tertutup & 4 & $4(100 \%)$ & $0(0 \%)$ & $2.0(1.2-3.2)^{*}$ \\
\hline Kandang terbuka & 16 & $8(50 \%)$ & $8(50 \%)$ & Referensi \\
\hline \multicolumn{5}{|l|}{ Pakan kuda berupa ampas tahu/tempe } \\
\hline $\mathrm{Ya}$ & 10 & $9(90 \%)$ & $1(10 \%)$ & $3.0(1.1-7.9)^{*}$ \\
\hline Tidak & 10 & $3(30 \%)$ & $7(70 \%)$ & Referensi \\
\hline \multicolumn{5}{|l|}{ Lokasi memotong rumput di pematang sawah } \\
\hline $\mathrm{Ya}$ & 15 & $7(46.7 \%)$ & $8(53 \cdot 3 \%)$ & Referensi \\
\hline Tidak & 5 & $5(100 \%)$ & $0(0 \%)$ & $2.1(1.3-3.7)^{*}$ \\
\hline \multicolumn{5}{|l|}{ Cara pemotongan rumput } \\
\hline Dipotong di bagian atas/daunnya saja & 16 & $8(50 \%)$ & $8(50 \%)$ & Referensi \\
\hline Dipotong dengan meninggalkan bagi & & & & \\
\hline $\begin{array}{l}\mathrm{cm} \\
\text { dari permukaan tanah }\end{array}$ & 4 & $4(100 \%)$ & $0(0 \%)$ & $2.0(1.2-3.3)^{*}$ \\
\hline \multicolumn{5}{|l|}{ Kuda dimandikan setiap hari } \\
\hline $\mathrm{Ya}$ & 10 & $5(50 \%)$ & $5(50 \%)$ & Referensi \\
\hline Tidak & 9 & $9(100 \%)$ & $0(0 \%)$ & $2.0(1.1-3.7)^{*}$ \\
\hline \multicolumn{5}{|l|}{ Tipe tempat minum kuda } \\
\hline Plastik & 18 & $10(55.6 \%)$ & $8(44.4 \%)$ & Referensi \\
\hline Semen & 2 & $2(100 \%)$ & $0(0 \%)$ & $1.8(1.2-2.7)^{*}$ \\
\hline
\end{tabular}

${ }^{*}$ Adanya asosiasi yang nyata pada $\mathrm{p}<0.05$.

terinfeksi Strongyle 3 kali lebih besar (SK 95\% RR: 1.17.9) dibandingkan kuda yang tidak diberikan pakan ampas tempe atau tahu. Ampas tahu maupun tempe memiliki kandungan air yang tinggi, sebesar 85.31\% (Suprapti, 2005). Kadar air suatu bahan dipengaruhi oleh temperatur dan kelembaban. Kelembaban yang tinggi akan menyebabkan terjadinya penyerapan uap air dari udara oleh bahan sehingga bahan menjadi lembab dan kadar air meningkat. Kadar air suatu bahan dapat menurun jika bahan dikeringkan atau terpapar temperatur tinggi. Jika temperatur udara tinggi, kelembaban akan rendah (Handoko, 2013). Derajat temperatur dan kelembaban tertentu dapat memberikan kondisi ideal bagi proliferasi dan kelangsungan hidup cacing parasit (Rosa et al., 2018). Ampas tahu maupun tempe diduga dapat menjadi berisiko terhadap kejadian infeksi Strongyle jika pakan tersebut terkontaminasi telur atau larva infektif (L3)
Strongyle karena ampas tahu maupun tempe tersebut menyediakan kondisi yang ideal bagi perkembangan cacing parasit.

Berdasarkan analisis lokasi pemotongan rumput, lokasi pemotongan rumput selain di pematang sawah memiliki hubungan terhadap kejadian helminthiasis. Hasil analisa data membuktikan bahwa lokasi pemotongan rumput selain di sekitar pematang sawah, seperti halaman rumah, lapangan, kebun, dan perumahan memiliki risiko terinfeksi Strongyle 2.1 kali lebih besar (SK 95\% RR: 1.3-3.7) dibandingkan di sekitar pematang sawah. Lokasi selain di sekitar pematang sawah tersebut diduga memiliki tingkat kontaminasi telur atau larva infektif di lingkungan yang lebih tinggi jika dibandingkan di sekitar pematang sawah. Lokasi selain di sekitar pematang sawah biasa digunakan oleh pemilik kuda untuk menernakkan atau mengumbar kudanya. Hal ini dapat meningkatkan risiko lingkungan terkontaminasi 
telur atau larva infektif dari feses kuda yang terinfeksi. Selain itu, lokasi sekitar pematang sawah memiliki temperatur yang tinggi serta terpapar sinar matahari langsung. Larva infektif akan segera mati jika terpapar kondisi lingkungan yang merugikan, seperti sinar matahari langsung dan perubahan temperatur (Nielsen et al., 2007).

Faktor lain yang dapat mempengaruhi tingkat kejadian infeksi Strongyle pada kuda berdasarkan penelitian ini yaitu cara pemotongan rumput. Rumput yang dipotong dengan meninggalkan bagian $<10 \mathrm{~cm}$ dari permukaan tanah memiliki risiko terinfeksi Strongyle 2 kali lebih besar (SK 95\% RR: 1.2-3.3) dibandingkan rumput yang dipotong di bagian atas/daunnya saja. L3 Strongyle bersifat fotofobia, yaitu larva akan naik ke permukaan rumput pada pagi hari dan turun kembali ke dasar rumput pada siang hari untuk menghindari temperatur tinggi (David, 2012). Pengambilan rumput pada pagi hari dengan cara meninggalkan $<10 \mathrm{~cm}$ bagian rumput dari permukaan tanah diduga akan meningkatkan kejadian infeksi cacing Strongyle pada kuda. Tingkat kejadian infeksi Strongyle dapat diturunkan dengan pemberian rumput yang telah dikeringkan atau dilayukan sebagai pakan kuda. Rumput kering akan meminimalkan kontaminasi larva infektif (L3) Strongyle (Saputra, 2016).

Berdasarkan hasil analisis dari aspek higiene kuda, kuda yang tidak dimandikan setiap hari memiliki risiko terinfeksi Strongyle 2 kali lebih besar (SK 95\% RR: 1.1-3.7) dibandingkan kuda yang dimandikan setiap hari. Hal tersebut diduga karena kuda yang dimandikan setiap hari dapat dibersihkan dari adanya feses yang terkontaminasi telur atau larva, yang masih menempel pada tubuh kuda. Apabila feses yang terkontaminasi masih menempel pada kuda, feses yang terkontaminasi dimungkinkan dapat jatuh dan mencemari lingkungan kandang. Hal ini dapat menyebabkan kejadian reinfeksi cacing saluran pencernaan pada kuda. Secara umum, kuda perlu dimandikan setiap hari setelah kuda bermain bebas di tempat pengumbaran atau setelah seharian diajak bekerja (Suparman, 2007).

Berdasarkan hasil analisis dari aspek sanitasi lingkungan perkandangan, tipe tempat minum kuda yang berbahan dasar semen memiliki risiko terinfeksi Strongyle 1.8 kali lebih besar (SK 95\% RR: 1.2-2.7) dibandingkan tempat minum kuda yang berbahan dasar plastik. Tipe tempat minum kuda yang berbahan dasar plastik memiliki permukaan yang lebih halus daripada tempat minum kuda yang berbahan dasar semen. Hal ini diduga membuat tempat minum kuda yang berbahan dasar plastik lebih mudah dibersihkan apabila terdapat telur cacing dari air yang terkontaminasi, yang menempel pada tempat minum. Perbedaan tingkat kebersihan secara teknis berkaitan dengan permukaan dan area. Permukaan yang tidak berpori dan halus lebih mudah dibersihkan dibandingkan dengan permukaan yang berpori dan kasar. Selain itu, tipe tempat minum kuda yang berbahan dasar plastik tidak bersifat permanen atau dapat diganti dengan yang baru apabila terjadi kerusakan, sehingga dapat meminimalkan adanya telur cacing yang menempel pada tempat minum.

"Penulis menyatakan tidak ada konflik kepentingan dengan pihak-pihak yang terkait dalam penelitian ini"

\section{DAFTAR PUSTAKA}

Andersen UV, Haakansson IT, Roust T, Rhod M, Baptiste KE, Nielsen MK. 2013. Developmental stage of Strongyle eggs affects the outcome variations of real-time PCR analysis. Vet Parasitol. 191(2013):191-196.

[ANRI] Arsip Nasional Republik Indonesia. 2017. Naskah Sumber Arsip Moda Transportasi Tradisional. Jakarta (ID): Arsip Nasional Republik Indonesia.

Ashenafi A, Samuel E, Natnael M, Shiret B. 2015. Prevalence of Gastro Intestinal Nematode Parasitic Infections of Horses and Donkeys in and Around Kombolcha town. Journal of Scientific Research. 10: 228-234.

Bevilaqua CML, de Rodrigues ML, Concordet D. 1993. Identification of infective larvae of some common nematode strongylids of horses. Reveu Méd Vét. 144(12):989-995.

David KH. 2012. Controlling Internal Parasites of Horse. Columbia (US): University Extension.

[Ditjen PKH] Direktorat Jenderal Peternakan dan Kesehatan Hewan. 2019. Populasi Kuda Menurut Provinsi Tahun 2015-2019. Jakarta (ID): Direktorat Jenderal Peternakan dan Kesehatan Hewan.

[ESCCAP] European Scientific Counsel Companion Animal Parasites. 2019. A Guide to The Treatment and Control of Equine Gastrointestinal Parasite Infections. $8^{\text {th }}$ Edition. Worcestershire (GB): ESCCAP.

Fathmanto M. 2008. Status Kesehatan dan Manajemen Pemeliharaan Kuda Delman di Kota 
Bogor [skripsi]. Bogor (ID): Institut Pertanian Bogor.

Fritzen B, Rohn K, Schnieder T, von SamsonHimmelstjerna G. 2010. Endoparasite control management on horse farms - lessons from worm prevalence and questionnaire data. Equine Vet J. 42:79-83.

Fowler ME, Mikota SK. 2006. Biology, medicine, and surgery of elephants. Iowa (US): Blackwell Publishing.

Handoko WA. 2013. Pengaruh Lama Penyimpanan dan Kombinasi Indigofera Zollingeriana dan Leucaena Leucocephala terhadap Kualitas Fisik Pellet [skripsi]. Bogor (ID): Institut Pertanian Bogor.

Harvey AM, Meggiolaro MN, Hall E, Wattsc ET, Rampa D, Šlapeta J. 2013. Wild horse populations in South-East Australia have a high prevalence of Strongylus vulgaris and may act as a reservoir of infection for domestic horses. IJP. 8:156-163.

Kornaś S, Cabaret J, Skalska M, Nowosad B. 2010. Horse infection with intestinal helminths in relation to age, sex, access to grass, and farm system. Vet Parasitol. 174:285-291.

Kooyman FNJ, van Doorn DCK, Geurden T, MughiniGras L, Ploeger HW, Wagenaar JA. 2016. Species composition of larvae cultured after anthelmintic treatment indicates reduced moxidectin susceptibility of immature Cylicocyclus species in horses. Vet Parasitol. 227:77-84.

Kuzmina TA, Dzeverin I, Kharchenko VA. 2016. Strongylids in domestic horses: influence of horse age, breed, and deworming programs on the Strongyle parasite community. Vet Parasitol. 227: 56-63.

Lem MF, Vincent KV, Pone JW, Joseph T. 2012. Prevalence and intensity of gastro-intestinal helminths in horses in the Sudano-Guinean climatic zone of Cameroon. Trop Parasitol. 2(1): 45-48.

Lyons ET, Tolliver SC. 2015. Strongyles in horses. UK Ag. Research. Kentucky (US): University of Kentucky.

Mangassa B, Tafese W. 2016. Prevalence of strongyle infection and associated risk factors in horse and donkeys in and around batu town, eastshoa, oromia regional state, ethiopia. Food Science and Quality Management. 54: 66-71

Matthews JB, Burden FA. 2013. Common helminth infections of donkeys and their control in temperate regions. Equi Vet Edu. 461-467.

Mfitilodze MW, Hutchinson GW. 1987. Development and survival of free-living stages of equine
Strongyles under laboratory conditions. Vet Parasitol. 23:121-133.

Nielsen MK, Kaplan RM, Thamsborg SM, Monrad J, Olsen SN. 2007. Climatic influences on development and survival of free-living stages of equine strongyles: implications for worm control strategies and managing anthelmintic resistance. Vet J. 174:23-32.

Relf VE, Morgan ER, Hodgkinson JE, Matthews JB. 2013. Helminth egg excretion with regard to age, gender, and management practices on UK thoroughbred studs. Parasitol. 140:641-652.

Rosa MHF, Garcia AM, Daher DO, Lima IG, Félix MB, Capellari LA, Ferreira F, Rocha CMBM. 2018. Factors associated with the prevalence of helminths in Mangalarga Marchador horses in southern of Minas Gerais, Brazil. Pesq Vet Bras. 38(6):1097-1104.

Santos DW, de Carvalho LMM, Molento MB. 2018. Identification of third larval types of cyathostomins of equids: an improved perspective. J Vetpar. 260:49-52.

Saputra DS. 2016. Infeksi Cacing Saluran Pencernaan pada Banteng (Bos javanicus d'Alton, 1823) di Taman Margasatwa Ragunan, Jakarta Selatan [skripsi]. Bogor (ID): Institut Pertanian Bogor.

Setiawan DK, Dwinata IM, Oka IBM. 2014. Identifikasi jenis cacing nematoda pada saluran gastrointestinal kuda penarik cidomo di Kecamatan Selong, Lombok Timur. Indo Med Vet. 3(5): 351-358.

Soares MP, Gozzelino R, Weis S. 2014. Tissue damage control in disease tolerance. Trend in Immunol. 35:483-494.

[Succeed]. 2015. Parasitism and its effects on equine gastrointestinal health [Internet]. [Tersedia pada: https://www.succeedequine. com/succeed blog/2015/06/05/parasitism-and-its-effects-onequine-gastrointestinal-health/. Diunduh Jun 7 2020.

Sultan A, Ayele G, Tadesse B, Ahmed A. 2013. Prevalence of gastrointestinal parasites of horses and donkeys in Kurfa Chale District, East Hararghe, Ethiopia. Livestock Research for Rural Development. 26:119.

Suparman. 2007. Pengayaan Seri Beternak: Beternak Kuda. Surabaya (ID): JP Books. hlm 26-27.

Thienpont D, Rochette F, Vanparijs OFJ. 1995. Diagnosing Helminthiasis Through Coprological Examination. New York (US): Appleton Century Crofts. 
96 | Shatyaayyupranathasari et al.

Wenda P, Lomboan A, Santa NM, Nangoy MJ. 2020. Profil manajemen kesehatan ternak kuda di Desa Pinabetengan Kecamatan Tompaso Kabupaten Minahasa. Zootec. 40(2):461-470.

Widnyana IGNP. 2013. Prevalensi infeksi parasit cacing pada saluran pencernaan sapi bali dan sapi rambon di Desa Wosu, Kecamatan Bungku Barat, Kabupaten Morowali. J Agro. 10(2): 40-45.
Willingham AL, Johansen MV, Barnes EH. 1998. A new technic for counting Schistosoma japonicum egg in pig feces. Southeast Asian J Trop Med Pub Health. 29(1):128-130.

Zajac AZ, Conboy GA. 2012. Veterinary Clinical Parasitology. 8th Edition. Iowa (US): Jhon Wiley \& Sons. 